\title{
Relationship between phenological and morphological characteristics of plant with popcorn races of a diversity microcenter in southern Brazil
}

\author{
Relação entre características fenológicas e morfológicas de plantas com raças de millho pipoca de \\ um microcentro de diversidade no sul do Brasil \\ Relación entre las características fenológicas y morfológicas de plantas con razas de maíz reventón \\ de un microcentro de diversidad en el sur de Brasil
}

Received: 06/02/2021 | Reviewed: 06/13/2021 | Accept: 06/17/2021 | Published: 06/29/2021

\author{
Francisco Wilson Reichert Júnior \\ ORCID: https://orcid.org/0000-0002-4501-898X \\ Federal University of Santa Catarina, Brazil \\ E-mail: chicowrj@gmail.com \\ Juliana Bernardi Ogliari \\ ORCID: https://orcid.org/0000-0003-2644-3179 \\ Federal University of Santa Catarina, Brazil \\ E-mail: juliana.bernardi@ufsc.br \\ Otávio Rechsteiner Maghelly \\ ORCID: https://orcid.org/0000-0001-9918-4177 \\ Federal University of Santa Catarina, Brazil \\ E-mail: otavio.maghelly@ufsc.br \\ Rosenilda de Souza \\ ORCID: https://orcid.org/0000-0001-7820-2516 \\ Federal University of Santa Catarina, Brazil \\ E-mail: rosenilda.agro@hotmail.com
}

\begin{abstract}
The far west region of Santa Catarina (FWSC) state in southern Brazil was indicated as a microcenter of diversity of the Zea genus. In this region, local popcorn varieties are grown in small areas, but in a significant number of farms. The present study aimed to characterize the diversity of 41 local populations from that region, based on phenology and morphological characters of plant, ear and grain. Therefore, an experimental design of complete randomized blocks with two replications was conducted. The data allowed to identify a rich diversity of popcorn in the FWSC for the characteristics of plant, ear, and grain, as well as for the phenology. For the color, 20 populations presented white grain, nine black, nine yellow, two red and one orange. Regarding the cycle, all varieties of yellow and round grains were considered hyper early/early and the varieties of white grains, intermediate/late. Average plant height varied from 1.8 to $3.2 \mathrm{~m}$, while the weight of one thousand kernels varied from 80.9 to $200.4 \mathrm{~g}$. The accumulated day degrees for tasseling ranged from 689.05 to $1,090.57$. Based on the cluster analysis of qualitative and quantitative characters, three groups were formed, and five populations were isolated. The inclusion of plant characteristics and phenology can be an important and complementary tool for studies in popcorn races. Trends in some plant characteristics were observed within popcorn varieties with the same grain features. This result is important information for popcorn genetic breeding strategies.
\end{abstract}

Keywords: Germplasm characterization; Popcorn; Genetic diversity; Landraces; Zea mays L.

\section{Resumo}

A região do Extremo Oeste de Santa Catarina (EOSC), no sul do Brasil, foi indicada como um microcentro de diversidade do gênero Zea. Nesta região, as variedades locais de pipoca são cultivadas em pequenas áreas, mas em um número significativo de propriedades. O presente estudo teve como objetivo caracterizar 41 populações locais de milho pipoca dessa região, com base em descritores fenológicos e morfológicos associados à planta, espiga e ao grão. Para tanto, foi realizado um experimento no delineamento de blocos completos casualizados com duas repetições. Os dados permitiram identificar uma rica diversidade de milho pipoca no EOSC para as características de planta, espiga e grão, bem como para a fenologia. Quanto à cor, 20 populações apresentaram grãos brancos, nove pretos, nove amarelos, duas vermelhos e uma alaranjado. Quanto ao ciclo, todas as variedades de grãos amarelos e redondos foram consideradas hiperprecoces/precoces e as variedades de grãos brancos foram intermediárias/tardias. A altura média de planta variou de 1,8 a 3,2 m, enquanto o peso de mil grãos variou de 80,9 a 200,4 g. O acúmulo de graus dia para o pendoamento variou de 689,05 a 1.090,57. Segundo a análise de agrupamento de caracteres qualitativos e quantitativos, três grupos foram formados e cinco populações ficaram isoladas. A inclusão de características de planta e fenologia pode ser uma 
ferramenta importante e complementar aos estudos de raças de milho pipoca. Tendências em alguns caracteres de planta foram observadas em variedades de milho pipoca com a mesma característica de grão. Este resultado é importante para a definição de estratégias de melhoramento genético dessa cultura.

Palavras-chave: Caracterização de germoplasma; Milho pipoca; Diversidade genética; Variedades crioulas; Zea mays L.

\section{Resumen}

La región del extremo oeste del estado de Santa Catarina (EOSC), en el sur de Brasil, fue indicada como un microcentro de diversidad del género Zea. En esta región, las variedades locales de maíz reventón se cultivan en áreas pequeñas, pero en un número significativo de propiedades. El presente estudio tuvo como objetivo caracterizar la diversidad de 41 poblaciones locales de este tipo de maíz de esa región, con base en la fenología y caracteres morfológicos de planta, mazorca y grano. Por lo tanto, se realizó un diseño experimental de bloques completos al azar con dos repeticiones. Los datos permitieron identificar una rica diversidad de maíz reventón en el EOSC por las características de planta, mazorca y grano, así como para la fenología. Para el color, 20 poblaciones presentaron grano blanco, nueve negros, nueve amarillos, dos rojos y uno naranja. En cuanto al ciclo, todas las variedades de granos amarillos y redondos se consideraron muy precoces/tempranas y las variedades de granos blancos, intermedias/tardías. La altura promedio de las plantas varió de 1,8 a 3,2 m, mientras que el peso de mil granos varió de 80,9 a 200,4 g. Los grados acumulados por día para la emisión de la espiga vario entre 689,05 y 1.090,57. Con base en el análisis de conglomerados de caracteres cualitativos y cuantitativos, se formaron tres grupos y se aislaron cinco poblaciones. La inclusión de las características de las plantas y la fenología puede ser una herramienta importante y complementaria para el estudio de las razas de maíz reventón. En algunas características se observaron tendencias de las plantas dentro de las variedades con la misma característica de grano. Este resultado es importante para el mejoramiento genético de este tipo de maíz.

Palabras clave: Caracterización de germoplasma; Maíz reventón; Diversidad genética; Variedades criollas; Zea mays L.

\section{Introduction}

Among the different types of maize, popcorn stands out for its culinary and cultural importance. It is characterized by the ability to expand the endosperm when exposed to heat. This characteristic is due to the physical and chemical components of the grain, which when heated, break the pericarp and expose the endosperm (Zinsly \& Machado 1978; Borras et al., 2006).

Until the early 2000s, most of the popcorn consumed in Brazil was imported. With the increase in national demand, production expanded, grain imports decreased and the import of American hybrid cultivars, registered by packaging companies, increased (Kist, 2018). Although the Brazilian market works mostly with a specific type of grain (the American type, which has round grain, medium to large size and yellow-orange color), popcorn presents great diversity for shape and grain color (Nobre, Liberalino Filho, Praça, Dias, \& Ferreira Neto, 2000; Sawazaki 2010; Paraginski et al., 2016). However, for both common maize and popcorn, this rich diversity outside of commercial standards is generally cultivated by indigenous peoples, quilombolas or small-scale farmers. It is also important for the conservation of the species and in breeding programs as a source of characteristics (Nass \& Paterniani 2000; Gorjanc, Jenko, Hearne, \& Hickey, 2016).

Commercial popcorn cultivars in Brazil did not get much attention on breeding programs in comparison with other corn kinds, so that they are relatively more susceptible to diseases and super-early in cycle, have in general more inbreeding depression, a fragile stem and greater prolificity, reduced expansion capacity, greater prolificity, in the addition to emitting tillers more frequently and have less developed root system, making them more susceptible to lodging (Vendruscolo et al., 2000; Miranda et al., 2003).

The limited genetic diversity of popcorn among modern cultivars and the little diversity represented in the main germplasm banks in the country have restricted the advances in popcorn breeding programs in Brazil (Silva et al., 2015) One of the ways to make breeding programs more efficient is to expand genetic diversity, and therefore, the identification of genetically contrasting materials with potential variability for selection is fundamental, being one of the pillars of breeding. Thus, the qualification and quantification of the genetic diversity present in germplasm banks, based on agronomic, morphological, biochemical and molecular characteristics, allow to define the priorities of activities related to the conservation of germplasm, participatory genetic breeding as well as to know the potential of using this germplasm in conventional genetic improvement 
programs (Munhoz, Priori, Amaral Júnior, Scapim, \& Simon, 2009; Paula et al., 2010).

In the Zea mays L. species, one initial way of classifying the diversity of populations is to define races. About 300 races of maize, widely distributed in the American continent, have already been classified in the western hemisphere (Nass \& Paterniani 2000; Vilaró, Vidal, \& Abadie, 2020), and new races being discovered recently (Silva, Vidal, \& Ogliari, 2016). A race is defined as a related group of populations with common characteristics that allow them to be recognized as a group (Anderson \& Cutler 1942), being considered one of the first levels of classification of diversity in maize collections. For the study of races, characteristics of ear and grain are considered since the classification is performed after harvest. However, the evaluation of plant characteristics could help to deepen the classification of races and contribute to popcorn breeding, since studies have demonstrated the possibility of the color of the grain to be related to heterotic groups in popcorn (Amaral Júnior et al., 2011; Vittorazzi et al., 2018).

Heterotic groups can be defined as a collection of germplasm that when crossed with accessions from another group present higher levels of heterosis than when crossed with accessions from the same group (Lee, 1995). The heterotic groups studies anchor specific crossing plans to obtain hybrids focused on different characteristics (Hallauer, Carena, \& Miranda Filho, 2010). Thus, classifying materials based on plant, ear and grain characteristics allow the identification of heterotic groups within and between races.

The municipalities of Anchieta and Guaraciaba in the far west of Santa Catarina (FWSC), southern Brazil, have a rich diversity of different kinds of corn conserved on farm. During the years 2011 and 2012, 1,513 local populations (common, popcorn, sweet and farinaceous) were identified in the region, of which 1,078 were popcorn, mostly preserved by women farmers. Due to this diversity of local varieties and the presence of wild corn relatives, this region was indicated as a microcenter of diversity of the Zea genus (Costa, Silva, \& Ogliari, 2016). After collecting populations in 2013 representing the local diversity of this microregion (Vidal, 2016, Vidal, Silva, \& Ogliari, 2018), a race study based on ear and grain characteristics was carried out by Silva et al. (2016), and from which they identified at least five races of popcorn, three of which were considered new. These races had two distinctives origins: one from the lowland populations of South America, and the other resulting from the selection of women farmers of the region, and subsequent diversification (Silva, Vidal, Ogliari, Costich, \& Chen, 2020).

Studies that aim to associate plant characteristics to popcorn races are inexistent, however they may be fundamental in understanding on the diversity of the species. Based on this perspective, the present study aimed to evaluate the diversity of 41 local popcorn populations from the collection of local popcorn varieties collected in the FWSC region to study the possible relations between the phenological and morphological characters of the plant, ear and grain characteristics.

\section{Methodology}

\subsection{Plant material}

In 2013, local popcorn populations were collected from small-scale farmers of two municipalities (Anchieta and Guaraciaba) in the FWSC, southern Brazil, to compose a nuclear collection based on the diversity conserved on farm in the region. The strategy for collecting populations considered diversity indexes from data on identification of the landraces, morphological characteristics of the grain, geographical location, and use values and conservation in the farmers' view, organized into 13 categories by Costa et al. (2016). Vidal (2016) and Vidal et al. (2018) chose M sampling method because it encompassed the greatest diversity with smaller sample size. This approach resulted in the popcorn collection of the Federal University of Santa Catarina (UFSC)' gene bank based on 174 populations from the FWSC. The identification of at least five races by Silva et al. (2016) considered morphological characters associated with the ear and grain of a sample of 70 popcorn populations from this collection. For this study, a sample of 41 local popcorn populations, representing four of the five races previously classified by Silva et al. (2016), were evaluated for phenology and morphological characteristics of the plant, ear and grain at the 
experimental farm of the Federal University of Santa Catarina, in Florianópolis - SC, in the 2017/2018 season.

\subsection{Study location and experimental design}

The municipality of Florianópolis is located at latitude $27.41^{\circ} \mathrm{S}$ and longitude $48.32^{\circ} \mathrm{O}$, at sea level; it has soil classified as typical Hydromorphic Quartzarenic Neosol by the Brazilian Soil Science Society (SBCS, 2004), an average annual temperature of $20.1^{\circ} \mathrm{C}$ and an average annual rainfall of $1,462 \mathrm{~mm}$.

The adopted experimental design was complete randomized blocks with two repetitions since the variables in question are part of the minimum descriptors for corn, and therefore, less subject to the influence of the heterogeneity of the growing environment. The experimental unit suggested by Neto (2013) for this kind of experiment consists of at least two rows of four linear meters with the spacing recommended for the crop. Thus, in this study, the experimental unit consisted of two rows of five linear meters spaced $0.8 \mathrm{~m}$ apart and $0.2 \mathrm{~m}$ between plants, with a central useful plot of $2.4 \mathrm{~m}^{2}$.

After thinning, a plant density of 62,500 plants $\mathrm{ha}^{-1}$ was established. This density was chosen because it is within the range recommended for the crop (Gama et al., 1990). Fertilization was carried out based on soil analysis and following fertilization and liming recommendations for the states of Rio Grande do Sul and Santa Catarina (SCBS, 2016).

\subsection{Phenological and morphological characterization}

The characterization of the populations was carried out based on the minimum descriptors for corn, published by the Ministry of Agriculture and Supply (Brazil, 1997) and by the International Plant Genetic Resources Institute (IPGRI, 2000). In total, 25 plant, ear and grain descriptors were evaluated, at different stages of crop development. The following quantitative characteristics were evaluated based on the average of 10 plants in the useful plot: (a) Plant height (m); (b) Ear height (m); (c) Ear height/plant height index; (d) Length of the tassel (cm); (e) Number of branches of the tassel; (f) Stem diameter (mm); (g) Leaves above the ear; (h) Prolificacy; (i) Number of adventitious roots; (j) Number of internodes; (k) Ear length (cm); (l) Ear Diameter (cm); (m) Grains per ear row; and (n) Number of ear rows. For the (o) weight of one thousand grains, 100 grains were randomly selected and weighed from each block, being then extrapolated to one thousand grains (the analysis was done in triplicate). From a sample of 10 grains from the central part of the row of five ears of the useful plot, the (p) caryopsis roundness index was evaluated by $\left(C I=L W T^{\frac{1}{3}} / L\right)$, being: $L-$ grain length; $W$ - grain width and $T$ - grain thickness. The qualitative characteristics evaluated based on the mode value of the corresponding grade scale were: (q) Grain color (1- yellow, 2 - black, 3 - white, 4 - red, 5 - orange); (r) Endosperm color (1 - yellow, 2 - colorless); (s) Grain shape (1 - round, 2 - pointed); (t) Anther pigmentation by anthocyanin ( 1 - present, 2 - absent); (u) Pigmentation of the stigma by anthocyanin (1 - present, 2 - absent); (v) Coleoptile pigmentation by anthocyanin (1 - present, 2 - absent); (x) Color of the cob (1 - White, 2 - red); (w) Position of the ear (1 - upright, 2 - oblique, 3 - decumbent); (y) Angle between leaf and stem (1 - Small, 2 - medium, 3 - large).

For the phenological characteristics, a random sample of 10 plants from the useful plot was evaluated, from emergence to physiological maturity in degrees days and days after emergence. The number of degree days was established by the thermal sum of the maximum and minimum daily averages, considering a basal temperature of $10^{\circ} \mathrm{C}$, from the time of emergence until the change of each phenological stage of 50\% + 1 plant of each plot. As reference point, the tasseling stage (VT) was used, and calculated using Equation (1).

$$
A D D=\sum_{i=1}^{n}\left(\frac{T_{\max }+T_{\min }}{2}-T_{b}\right)
$$

where $\mathrm{T}_{\max }$ and $\mathrm{T}_{\min }$ refer, respectively, to the daily maximum and minimum air temperatures $\left({ }^{\circ} \mathrm{C}\right)$, and $\mathrm{T}_{\mathrm{b}}$ to the lower basal temperature $\left(10^{\circ} \mathrm{C}\right)$ of the crop. 


\subsection{Data analysis}

Characterization data for qualitative variables were analyzed using descriptive statistics (absolute and relative frequencies). Also, the analysis of variance (ANOVA) was performed to verify the quantitative characteristics that present a significant difference $(p \leq 0.05)$ between the populations by the $\mathrm{F}$ test. To have a reasonable estimate of the error, it is needed a reasonable number of degrees of freedom of the experimental error. It is advised a minimum number of 20 degrees of freedom of the error to achieve the desired degree of accuracy (Souza, Ethur, Lopes, \& Zanini, 2002). Since the degrees of freedom of the experimental error were 40 in this research, ANOVA could be performed. The characteristics that did not differ between the populations were eliminated from the following analyzes.

In order to understand the relationships between the quantitative characteristics, Pearson's correlation analysis was performed based on the average of each characteristic. For the variables that showed a high correlation $(r>0.8)$, one of them was eliminated from the following analyzes along with those with the lowest overall diversity.

Thus, the cluster analysis was performed based on 18 quantitative and qualitative morphological characteristics of the plant, ear and grain i.e., accumulated degree-days, ear height/plant height index, tassel length, tassel branches, prolificacy, number of internodes, stem diameter, adventitious roots, ear length, ear diameter, grains per ear row, number of ear rows, weight of one thousand grains, caryopsis roundness index, grain color, endosperm color, grain shape and cob color. The Gower similarity index (Gower, 1971) and clustering by UPGMA algorithm were used for the analysis of diversity, based on a matrix of all the qualitative data and the quantitative variables that met the criteria described above. For quantitative variables, mathematical averages were used, and the mode for the qualitative variables.

Principal component analysis (PCA) (Abdi \& Williams, 2010) was performed using the sample covariance matrix of standardized quantitative data, to clarify the interrelationships between population variables. For the variables that showed a correlation greater than 0.8 , one of them was removed from the principal component analysis. Thus, the variables utilized for the (PCA) were tassel branches, prolificity, grains per row, leaves above ear, tassel length, stem diameter, adventitious roots, number of internodes, accumulated degrees days, ear height/plant height index, ear length, caryopsis roundness index, number of grains per row, thousand grains weight and ear diameter.

The diversity data obtained from the qualitative and quantitative variables were analyzed using the PAST 3.04 software (Hammer, Harper, \& Ryan, 2001).

\section{Results}

\subsection{Morphological Characterization}

The morphological characterization demonstrated that the local popcorn populations of the FWSC present diversity for qualitative and quantitative characteristics.

The qualitative characteristics of the vegetative and reproductive phases were distributed as follows: presence of pigmentation in the coleoptile by anthocyanin (82.9\%) and absence of pigmentation (17.1\%); intermediate angle between leaves and stem (95.2\%) and small angle (4.8\%); rounded/spatulated format of the first leaf (100\%); presence of pigmentation in the stigma by anthocyanin $(56.09 \%)$ and absence of pigmentation (43.91\%); absence of anther pigmentation by anthocyanin (73.2\%) and presence of pigmentation (26.8\%); erect position of the ears (87.8\%) and decumbent position (12.2\%).

Regarding the color, nine varieties had yellow grains, two were red, nine were black, 11 were white and one was orange. All populations of red, black, and orange color showed grain with a rounded shape. For yellow grain populations, only the 2152A population had a pointed shape. White colored grain populations showed greater diversity for this characteristic, containing four populations with rounded grains and seven with pointed grains.

Most of the quantitative characteristics presented significant differences by the $\mathrm{F}$ test $(p \leq 0.05)$, except for the number 
of leaves above the ear. Since this characteristic did not contribute to the overall diversity of the populations, it was excluded from further analysis. The variation between populations for the quantitative characteristics is shown in Table 1 .

Table 1. Average, range, coefficient of variation (CV\%) and significance of the F-test of morphological descriptors evaluated between 41 local FWSC popcorn populations. Parameters obtained from the average between populations and ANOVA.

\begin{tabular}{lllll}
\hline Descriptor & Average & Range & CV (\%) & F- test \\
\hline Tasseling ADD & $909.35^{\mathrm{a}}$ & $689.05-1090.57$ & 2.24 & $0.0^{* * *}$ \\
Plant height $(\mathrm{m})$ & $2.58^{\mathrm{b}}$ & $1.8-3.22$ & 5.40 & $0.0^{* * *}$ \\
Ear height (m) & $1.41^{\mathrm{b}}$ & $0.64-2.22$ & 4.46 & $0.0^{* * *}$ \\
Number of leaves above ear & $5.5^{\mathrm{b}}$ & $5-6$ & 9.83 & $2.114^{\mathrm{ns}}$ \\
Stem diameter (mm) & $15.56^{\mathrm{b}}$ & $13.35-19.05$ & 5.95 & $0.001^{* * *}$ \\
Number of branches of the tassel & $18.94^{\mathrm{b}}$ & $12.35-26.54$ & 7.76 & $0.0^{* * *}$ \\
EH/PH Index & $0.53^{\mathrm{c}}$ & $0.35-0.68$ & 6.22 & $0.0^{* * *}$ \\
Prolificacy & $1.94^{\mathrm{c}}$ & $1.2-2.6$ & 10.69 & $0.005^{* *}$ \\
Ear length (cm) & $15.59^{\mathrm{d}}$ & $12.7-20.3$ & 2.53 & $0.0^{* * *}$ \\
Ear diameter (mm) & $31.77^{\mathrm{d}}$ & $23.3-42.5$ & 4.20 & $0.0^{* * *}$ \\
Circularity index & $0.73^{*}$ & $0.64-0.80$ & 3.07 & $0.001^{* * *}$ \\
Thousand grain weight & $139.13^{\mathrm{e}}$ & $80.9-200.4$ & 1.66 & $0.0^{* * *}$ \\
\hline
\end{tabular}

${ }^{a}$ Calculated from the moment when $50 \%+1$ of the plants in the plot reached VT. ${ }^{\mathrm{b}}$ Average obtained from two repetitions, estimated from ten plants of the useful plot. ${ }^{c}$ Index obtained by dividing the height of the plant by the height of the main ear. ${ }^{\mathrm{d}}$ Average obtained from a sample of five ears of each block. ${ }^{\mathrm{e}}$ Average obtained by the average weight of 300 grains per block. ${ }^{*}$ Significant at $5 \%$ error probability in F test. ${ }^{\text {ns }}$ Non-significant. Source: Authors.

Table 1 shows the wide range of values for most of the morphological characteristics of FWSC populations, which is important because it shows the great diversity present in the region. In relation to the average plant height of the populations, three had height less than $2.0 \mathrm{~m}$ (2425A, 2138B and 1110A), 13 between 2.0 and 2,5 (2255B, 2604B, 760A, 1119X, 2526C, 2359B, 2304A, 2438D, 123C, 2489E, 2079A, 2488A and 229B), 20 between 2.5 and $3.0 \mathrm{~m}$ (123B, 778B, 2091A, 2454A, 574A, 977A, 2108A, 2312A, 2423A, 2393B, 1100B, 2093A, 2376X, 2305A, 236B, 2379A, 2241A, 2152A, 2376 and 2279X), and five over $3.0 \mathrm{~m}$ (2110A, 2015A, 2101B, 2358A and 407X).

For the ear height/plant height index (EH/PH), the minimum and maximum values were $0.36(2425 \mathrm{~A})$ and 0.69 (407X), respectively. Ten populations showed values below 0.5 (2425A, 2138B, 1110A, 1119X, 760A, 2255B, 2359B, 2526C, 2423A and 2093A), 23 populations between 0.5 and 0.6 (123B, 2604B, 2438D, 2454A, 977A, 2091A, 778B, 2376X, 229B, 2489E, 123C, 2304A, 574A, 2488A, 1100B, 2393B, 2379A, 2152A, 2305A, 2108A, 2015A, 2241A and 2279X), and eight populations over 0.6 (2312A, 2376, 2079A, 2110A, 2101B, 2358A, 236B and 407X). The EH/PH index represents the ratio of ear height and plant height; values above 0.6 indicate that the ear is remarkably high in relation to the height of the plant, which may contribute to the lodging of the plants (Zsubori et al., 2002).

For the variable number of ears per plant, the average was 1.94 ears per plant, with the mode being 2.0 ears for the majority of the varieties. Two populations showed mode of 3 ears per plant, three populations showed a mode of 1 ear and an average of 1.2 (2241A), $1.3(2358 \mathrm{~A})$ and 1.4 (977A) ears. Thus, it is worth mentioning that there is intrapopulation genetic variability for this characteristic, with populations ranging from 1 to 4 ears per plant. 
For the caryopsis circularity index, which corresponds to how spherical the popcorn grain is, the populations ranged from 0.64 to 0.8 , with an average of 0.73 . The closer to 0.5 the index value is, the more similar the grain dimensions are. The populations with indexes closer to 0.5 were $2138 \mathrm{~B}, 2425 \mathrm{~A}$ and $977 \mathrm{~A}$, with values of $0.64,0.66$ and 0.67 , respectively.

As for the weight of one thousand grains, the range was 80.9 to $200.4 \mathrm{~g}$, with an average of 139.13 (Table 1). Five of the nine populations that showed black grain color were those that obtained the lowest values for weight of one thousand grains. The populations with the lowest and highest values were 2079A and 2279X with values of 80.9 and $200.4 \mathrm{~g}$, respectively. The white grain populations were those that showed the greatest variation for this characteristic, ranging from 113.2 to $176.2 \mathrm{~g}$.

Grain size, according to the American classification for popcorn grains (Srdić, Milašinović, Radosavljević, Kravić, \& Babić, 2017), measured by the number of grains in $10 \mathrm{~g}, 14$ populations had large grains (less than 67 grains in $10 \mathrm{~g}$ ) (977A, 2489E, 2138B, 2379A, 1119X, 574A, 1100B, 2312A, 2358A, 2241A, 2393B, 2110A, 2108A and 2279X), 12 populations showed medium grains (between 67 and 76 grains in $10 \mathrm{~g}$ ) (2152A, 2454A, 2359B, 2091A, 1110A , 2255B, 2305A, 2425A, 2376, 407X, 123C and 2376X), and 15 populations presented small grains (more than 76 grains in $10 \mathrm{~g}$ ) (2079A, 2526C, 236B, 2101B, 2304A, 229B, 2015A, 2488A, 760A, 2093A, 123B, 778B, 2438D, 2604B and 2423A). The population 2079A was the one with the highest average of grains in $10 \mathrm{~g}$ (123.6) and the population 2279X was the one with the lowest average (49.9).

Correlational analysis indicates the relationship between two linear variables and values will always be between +1 and -1. The sign indicates the direction, whether the correlation is positive or negative (positive when the value of one variable increase causes the increase of another variable; negative when the increase of one variable causes the reduction of the value of another), and the value of the correlation coefficient indicates the strength of the correlation between two variables. Pearson's correlation analysis showed a moderate (0.67) correlation between accumulated day degrees until tasseling and plant height (Table 2). There was a positive correlation between the weight of one thousand grains and the ear diameter (0.65), indicating that ears with a larger diameter had a greater weight of a thousand grains. There was also a moderate negative correlation between ear diameter and prolificacy (-0.44), suggesting that the more prolific the population, the smaller the main ear diameter. The quantitative variables that presented significant correlation in the Pearson's correlation analysis are shown in Table 2. 
Table 2. Correlation between accumulated degree days to tasseling (ADD), weight of one thousand grains (TGW) and prolificacy (PROL) among themselves and nine other variables evaluated in popcorn populations collected at far western Santa Catarina.

\begin{tabular}{|c|c|c|c|c|c|c|}
\hline \multirow{2}{*}{ Variable } & \multicolumn{2}{|l|}{ ADD } & \multicolumn{2}{|l|}{ TGW } & \multicolumn{2}{|c|}{ PROL } \\
\hline & $\mathrm{COR}^{1}$ & $p$ (uncorr) $)^{2}$ & COR & $p$ (uncorr) & COR & $p$ (uncorr) \\
\hline $\mathrm{PH}$ & 0.67 & $1.55 \mathrm{E}-06^{*}$ & 0.19 & 0.21 & -0.20 & 0.20 \\
\hline EH/PH & 0.70 & $3.13 \mathrm{E}-07 *$ & 0.071 & 0.65 & -0.10 & 0.51 \\
\hline TB & 0.059 & 0.71 & -0.23 & 0.13 & 0.20 & 0.19 \\
\hline SD & 0.28 & 0.066 & -0.05 & 0.71 & 0.07 & 0.66 \\
\hline EL & 0.21 & 0.17 & 0.51 & $5.96 \mathrm{E}-04 *$ & -0.08 & 0.60 \\
\hline ED & 0.18 & 0.23 & 0.65 & $3.87 \mathrm{E}-06^{*}$ & -0.44 & $0.003^{*}$ \\
\hline GR & -0.25 & 0.10 & -0.28 & 0.066 & 0.11 & 0.48 \\
\hline NR & -0.12 & 0.44 & 0.07 & 0.63 & -0.07 & 0.62 \\
\hline CI & 0.031 & 0.84 & -0.25 & 0.10 & 0.17 & 0.28 \\
\hline ADD & - & - & 0.076 & 0.63 & -0.22 & 0.16 \\
\hline TGW & 0.076 & 0.63 & - & - & -0.17 & 0.26 \\
\hline PROL & -0.22 & 0.16 & -0.17 & 0.26 & - & - \\
\hline
\end{tabular}

${ }^{1}$ Pearson's correlation; ${ }^{2}$ Significance of Pearson's correlation; PH - Plant height; EH/PH - Plant height/Ear height index; TB - Tassel branches; SD - Stem diameter; EL - Ear length; ED - Ear diameter; GR - Grains per row; NR Number of rows; CI - Caryopsis roundness index; TGW - Thousand grain weight; PROL - Prolificity; ADD Accumulated degree days. * Significant correlation at 5\%. Source: Authors.

\subsection{Phenology}

The climatological data of the place during the execution of the experiment are shown in Table 3. It was possible to observe that the maximum and minimum average temperatures during the development of the culture presented little variation and are within the average for the place. However, the rains were poorly distributed. While in January it rained above average, in February rainfall was much less than average for the location.

Table 3. Climatological data during the development of the crop. Florianópolis - Santa Catarina - Brazil.

\begin{tabular}{llll}
\hline & Max. Temp. Average ${ }^{\circ} \mathrm{C}$ & Min. Temp. Average ${ }^{\circ} \mathrm{C}$ & Precipitation (mm) \\
\hline nov/2017 & 25.27 & 18.19 & 142.1 \\
dez/2017 & 26.7 & 20.98 & 167.6 \\
jan/2018 & 28.6 & 21.6 & 489.2 \\
fev/2018 & 28 & 20.8 & 68.6 \\
mar/2018 & 27.8 & 21.4 & 183.9 \\
\hline
\end{tabular}

Source: Authors.

In Brazil, for the classification of maize cultivars according to the cycle, in accumulated degrees day (ADD) until tasseling, hyper-early varieties are defined as those with accumulation less than 790 ADD; early > 790 and < 830 ADD; intermediates > 830 and < 889 ADD, and late > 890 ADD (Ritchie, Hanway, \& Benson, 2003). The phenological cycle of the populations in this study is ordered according to the classification in Table 4. 
Table 4. Classification of local popcorn populations from the far western Santa Catarina regarding accumulated degrees day (ADD) from emergence to tasseling.

\begin{tabular}{ll}
\hline Cycle & Populations \\
\hline Hiper-early & 2255B, 1119X, 1110A, 760A, 2438D, 2359B, 2425A, 2489E, 2138B \\
\hline Early & 2423A, 2604B, 2152A \\
\hline Intermediate & $2488 \mathrm{~A}$ \\
\hline Late & 123B, 2101B, 2093A, 2304A, 2358A, 2393B, 778B, 2376, 229B, 1100B, 2312A, \\
& 2108A, 2279X, 2454A, 2079A, 2091A, 2526C, 123C, 2376X, 2379A, 2015A, \\
& 2110A, 574A, 236B, 407X, 2241A, 977A, 2305A \\
\hline
\end{tabular}

Source: Authors.

Most of the populations that had yellow grains showed ADD until tasseling less than 800 (2255B, 1119X, 1110A, 760A, 2438D, 2359B, 2425A and 2138B), except population 2152A, which had an accumulation of 828.25 ADD. Among black grain populations, there was greater variation, with a minimum accumulation of $825.1 \mathrm{ADD}(2604 \mathrm{~B})$ and a maximum of 1,030.8 ADD (236B). Among populations with white grain color, only one population had an accumulation of less than 900 ADD (2488A) until tasseling, the largest with an accumulation of 1,090.57 (2305A). The population 2279X of red color and greater weight of one thousand grains accumulated 961.37 ADD until tasseling. The 2489E red colored population accumulated 760.56 ADD and the 2423A orange colored population accumulated 822.12 ADD.

In relation to days after emergence until tasseling, the hyper-early varieties presented an average of 54.7 days; the early 59.3; the intermediate of 64; and the late ones ranged between 64 and 77 days, with an average of 69.6 days. Until physiological maturity in days after emergence, hyper-early populations took 106.6 days on average to complete the cycle, early 113 days, intermediate 122 days and late ranged from 122 to 138 days.

\subsection{Diversity analysis}

For cluster analysis (Figure 1), all the quantitative variables related to plant were used, and phenological cycle (until tasseling). For the ear and grain characteristics were used grain color, endosperm color, cob color, ear diameter, number of rows per ear, weight of a thousand grains and index of circularity of caryopsis. Therefore, 18 characteristics of plant, ear and grains in total were used.

It was possible to observe that most populations were grouped mainly in relation to the color of the grains and cycle (Figure 1). However, the population 2358A, despite having white grains, was isolated from the cutoff point because it had an ear diameter $(42.5 \mathrm{~mm})$ greater than the average of the other white varieties $(33.5 \mathrm{~mm})$. The population $2152 \mathrm{~A}$, despite having yellow grain color, has a longer cycle and pointed-shape grain, which separated it from the other yellow populations. The population 2279X, for having a longer cycle than the other population of red grain and weight of a thousand grains greater than the other populations, was also isolated in the cluster. Population 2423A was isolated in the cluster analysis because of its orange grain and red cob color. In addition, it presented an average of 18 grain rows per ear, higher than the other populations. The population 2489E showed characteristics of plant, ear, and grain similar to the yellow-colored varieties; however, as it has a longer cycle and red coloration of grains and cob, it was isolated in the cluster. A summary of the morphological groups is shown in Table 5. 
Table 5. Morphological groups based on plant, ear, grain and cycle characteristics and their respective populations of FWSC popcorn.

\begin{tabular}{|c|c|c|c|c|c|c|c|c|c|}
\hline MG & GC & $\mathbf{P H}$ & ED & NR & PRO & ADD & TGW & $\mathbf{N}$ & Pop. \\
\hline \multirow[t]{10}{*}{ (I) } & Black & 2.52 & 26.7 & 14 & 2.1 & 931.5 & 110.4 & 9 & \\
\hline & & 2.13 & 27.2 & 14 & 2.2 & 825.1 & 129.4 & & 2604B, \\
\hline & & 2.58 & 28.1 & 14 & 1.7 & 894.2 & 124.4 & & 123B \\
\hline & & 2.45 & 27.3 & 14 & 1.8 & 968.5 & 80.9 & & 2079A, \\
\hline & & 2.26 & 24.1 & 14 & 1.9 & 978.1 & 87.0 & & $2526 \mathrm{C}$ \\
\hline & & 3.17 & 28.6 & 14 & 1.8 & 895.7 & 102.0 & & 2101B, \\
\hline & & 2.78 & 26.1 & 12 & 2.2 & 1030.8 & 90.9 & & $236 \mathrm{~B}$ \\
\hline & & 2.73 & 28.5 & 14 & 2.3 & 900 & 123.7 & & 2093A, \\
\hline & & 2.28 & 27.8 & 14 & 2.1 & 911.3 & 106.7 & & 2304A, \\
\hline & & 2.35 & 23.3 & 14 & 2.6 & 978.7 & 145.3 & & $123 \mathrm{C}$ \\
\hline \multirow[t]{22}{*}{ (II) } & White & 2.74 & 33.5 & 14 & 1.8 & 986.8 & 147.9 & 19 & \\
\hline & & 2.46 & 29.6 & 14 & 2 & 874.4 & 120.5 & & 2488A, \\
\hline & & 2.61 & 30.5 & 14 & 1.9 & 973.7 & 138.4 & & 2091A, \\
\hline & & 2.46 & 32.7 & 16 & 2.2 & 941.8 & 113.2 & & 229B \\
\hline & & 2.71 & 32.6 & 14 & 2.2 & 932.6 & 173.0 & & 2393B, \\
\hline & & 2.70 & 33.1 & 12 & 1.8 & 950.4 & 162.5 & & 2312A, \\
\hline & & 2.68 & 32.7 & 14 & 2 & 954.3 & 176.2 & & 2108A, \\
\hline & & 2.81 & 31.1 & 14 & 2.1 & 998.2 & 153.0 & & 2379A, \\
\hline & & 3.22 & 34.2 & 14 & 1.8 & 1048.0 & 144.6 & & 407X, \\
\hline & & 2.72 & 35.8 & 16 & 1.9 & 943.1 & 162.3 & & 1100B \\
\hline & & 2.94 & 36.8 & 16 & 2.1 & 939.3 & 142.5 & & 2376 \\
\hline & & 2.75 & 35.8 & 16 & 2.1 & 996.8 & 147.3 & & $2376 X$ \\
\hline & & 3.08 & 33.2 & 16 & 1.6 & 1005.6 & 119.0 & & $2015 \mathrm{~A}$ \\
\hline & & 3.05 & 34.2 & 14 & 2 & 1007.5 & 173.0 & & 2110A, \\
\hline & & 2.77 & 32.7 & 14 & 1.7 & 1090.5 & 142.1 & & $2305 \mathrm{~A}$ \\
\hline & & 2.65 & 31.1 & 16 & 1.4 & 1083.1 & 149.8 & & 977A, \\
\hline & & 2.65 & 33.2 & 14 & 2.1 & 963.8 & 136.7 & & 2454A, \\
\hline & & 2.65 & 34.4 & 14 & 1.9 & 1030.5 & 160.8 & & 574A, \\
\hline & & 2.86 & 38.4 & 14 & 1.2 & 1079.0 & 171.8 & & 2241A, \\
\hline & & 2.59 & 35.4 & 14 & 1.9 & 936.2 & 124.6 & & $778 B$ \\
\hline & White & 3.17 & 42.5 & 16 & 1.3 & 917.81 & 163.5 & 1 & $2358 \mathrm{~A}$ \\
\hline & Red & 2.96 & 38.4 & 14 & 1.9 & 961.37 & 200.4 & 1 & $2279 X$ \\
\hline \multirow[t]{5}{*}{ (III) } & Yellow & 2.08 & 30.9 & 14 & 1.9 & 732.5 & 140.1 & 8 & \\
\hline & & 1.86 & 33.8 & 16 & 1.8 & 762.6 & 152.9 & & 2138B \\
\hline & & 2.12 & 31.2 & 16 & 2.1 & 689.0 & 141.9 & & 2255B \\
\hline & & 1.80 & 32.2 & 14 & 2 & 741.4 & 142.5 & & $2425 \mathrm{~A}$ \\
\hline & & 2.22 & 31.3 & 14 & 1.8 & 728.8 & 159.6 & & 1119X \\
\hline
\end{tabular}




\begin{tabular}{|c|c|c|c|c|c|c|c|c|}
\hline & 2.27 & 29.5 & 14 & 2 & 740.2 & 137.8 & & 2359B, \\
\hline & 1.93 & 30.5 & 14 & 1.8 & 730.9 & 139.6 & & 1110A, \\
\hline & 2.17 & 28.7 & 14 & 2 & 731.7 & 121.9 & & $760 \mathrm{~A}$, \\
\hline & 2.30 & 30.2 & 14 & 2 & 735.4 & 125.0 & & 2438D \\
\hline Yellow & 2.90 & 32.8 & 16 & 2.6 & 828.25 & 134.6 & 1 & $2152 \mathrm{~A}$ \\
\hline Red & 2.36 & 38.4 & 14 & 1.9 & 760.56 & 152.3 & 1 & $2489 E$ \\
\hline Orange & 2.71 & 33 & 18 & 1.9 & 822.12 & 131 & 1 & $2423 \mathrm{~A}$ \\
\hline
\end{tabular}

MG Morphological group; GC Grain color; PH Plant height (m); ED Ear diameter (average) (mm); NR Number of rows (mode); PROL Prolificity (average); ADD Accumulated degrees day (average); TGW Thousand grain weight (average) $(\mathrm{g})$; N Number of populations. Bold numbers represent the group average. Source: Authors.

Figure 1. Clustering of popcorn populations conserved in the FWSC, generated from the Gower similarity index and UPGMA algorithm. Cophenetic correlation $=0.84$. I: Black grain populations; II: White grain populations; III: Yellow grain populations

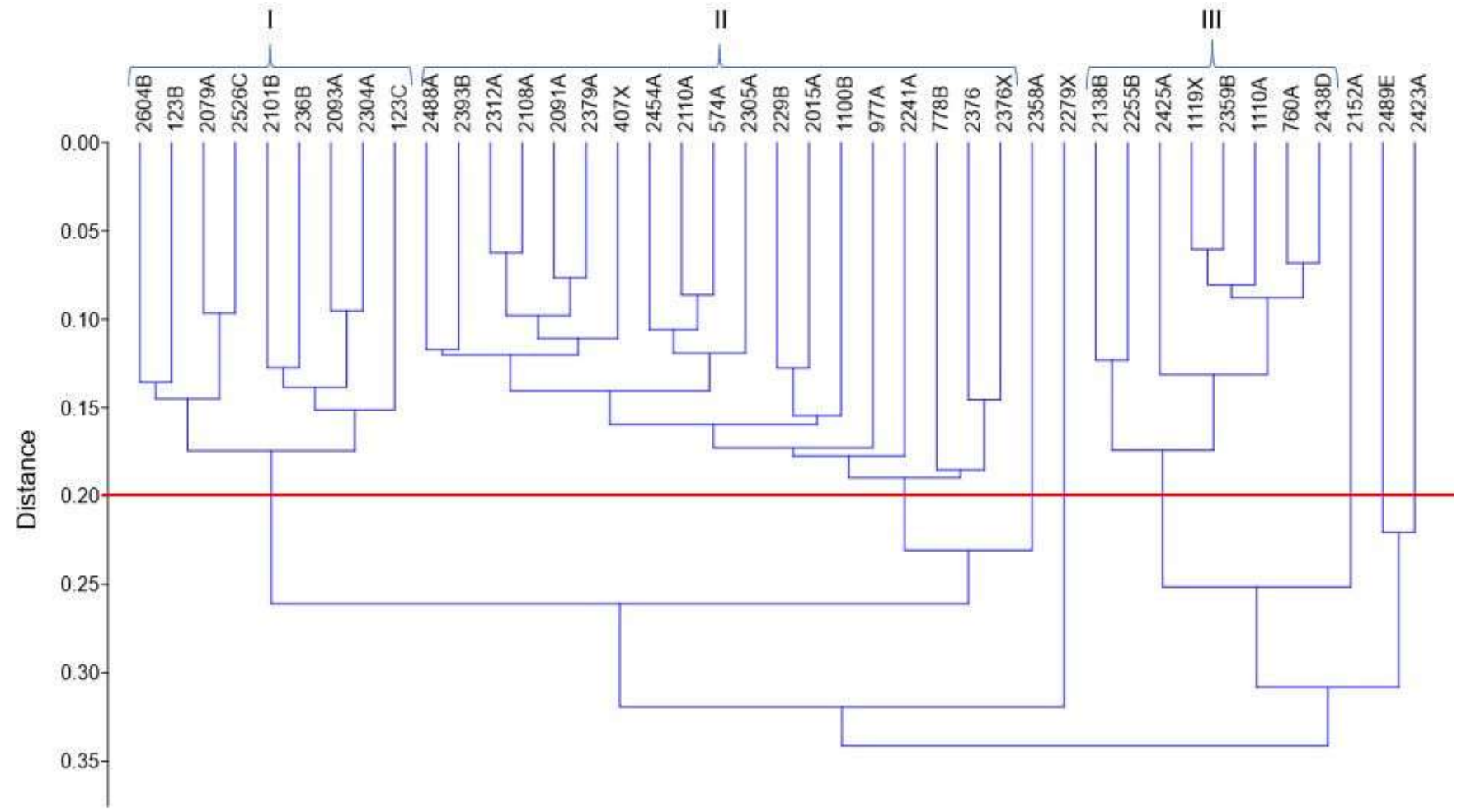

Source: Authors.

Group I contemplate nine populations (2604B, 123B, 2079A, 2526C, 2101B, 236B, 2093A, 2304A and 123C), all have black grain color, rounded grains, and average weight of one thousand grains lower than the other populations. They are more prolific, on average, have a smaller ear diameter and greater number of tassel branches. However, they have great amplitude in relation to the cycle, varying from 825.1 to $1,030.8$ ADD until tasseling.

Group II consists of 19 populations (2488A, 2091A, 229B, 2393B, 2312A, 2108A, 2379A, 407X, 1100B, 2376, 2376X, 2015A, 2110A, 2305A, 977A, 2454A, 574A, 2241A, 778B) and all have white colored grains and predominantly with pointed shape. However, it is the group that has the greatest diversity for plant morphological characteristics, with plant height ranging from 2.46 to 3.22 meters, ADD ranging from 874.4 to 1090.5 and stem diameter from 13.39 to 17.34 mm. Except for population 
2488A, all other populations in this group need to accumulate more than 900 ADD to achieve tasseling; and it also is the group with the highest $\mathrm{EH} / \mathrm{PH}$ values.

Group III is formed by eight populations (2138B, 2255B, 2423A, 1119X, 2359B, 1110A, 760A and 2438D) and all have yellow and round grains. This group is characterized by early populations for tasseling ( $<70$ ADD). In addition, they have a lower EH/PH index, and lower values for plant height. It is important to notice in table 5 that the bold numbers represent the average value for those characteristics in each group, and the differences between the groups for some characteristics such as lower PH for the yellow populations, lower TGW for the black populations and higher ADD for white populations.

The representation of the first two principal components (PC) (Figure 2) extracted from the analysis of 15 quantitative variables shows a similar clustering to that found in the cluster analysis. PC 1, 2 and 3 explain 53\% of the phenotypic variation. The first PC explains $23.5 \%$ of the total variation. In this axis, the variable with the highest weight was ADD, followed by the number of internodes (NI) and the ear diameter (ED). The second PC explains about $17.5 \%$ of the total variation and the explanatory variables for this axis were tassel branches (TB) and weight of one thousand grains (TGW). The third PC accounts for $11.5 \%$ of the entire variation, and the explanatory variables were tassel length (TL) and caryopsis roundness index (CI). This representation of the variation can be observed from the cluster analysis since the characteristic with more weight in the PC1 was ADD until tasseling, the early cycle populations were clustered together and, as they share the same grain color (yellow color), the combined effects of this characteristics resulted in the observed pattern in the cluster. The same logic for the populations with white grain color, as they have longer cycle. The populations of black colored grains showed an intermediate/late trend in the cycle. Of the ten varieties of black color only one accumulated more than 1,000 degrees for tasseling, and three needed less than 900, while among the white populations, seven needed more 1,000 degrees for tasseling and only one needed less than 900 .

Figure 2. Representation of the first two components that explain $39.9 \%$ of the total variation, extracted from 14 quantitative morphological and phenological variables of 41 popcorn populations conserved in the FWSC. • Represent black grain populations; $\quad$ Yellow; $\diamond$ White; $\Delta$ Red; $\nabla$ Orange.

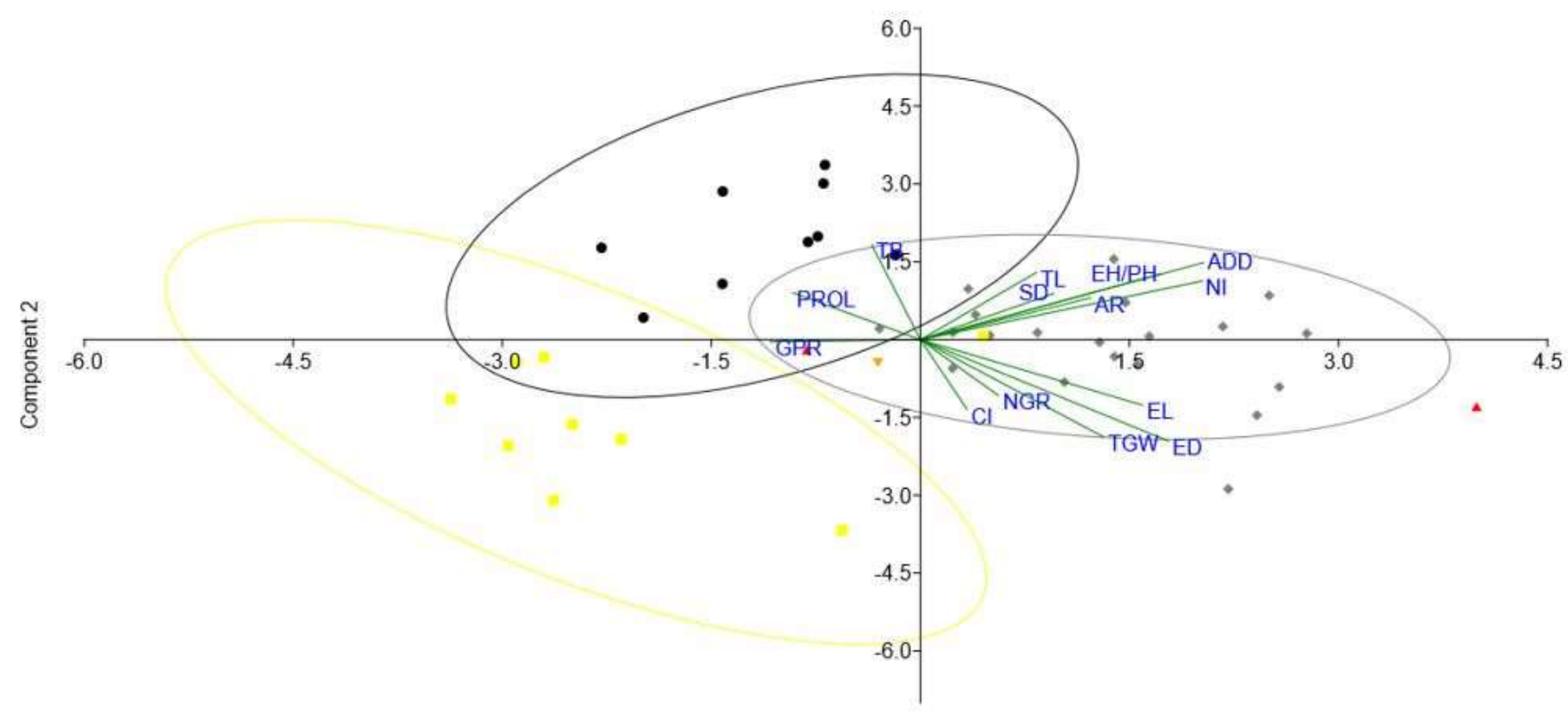

Component 1

Source: Authors. 
It is important to note that the black grain populations were clustered due to their higher prolificacy (PROL) and tassel branches (TB) and lower values of thousand grain weight (TGW), ear length (EL) and ear diameter (ED), as demonstrated by the green lines of Figure 2. The yellow grain populations were clustered in the opposite side of the accumulated degree days (ADD), ear height/plant height index (EH/PH) and number of internodes (NI) lines, since they presented the lowest values for these characteristics. The white grain populations, in turn, were clustered due the highest values of ADD, EH/PH, TGW and NI. Therefore, the main information that can be noticed in Figure 2 is that the varieties with similar grain colors tended to cluster by the most prominent features of their group.

\section{Discussion}

The results prove that the local popcorn maize populations of the FWSC have variability for most of the evaluated characteristics.

Of the 41 populations evaluated, 15 had plant height less than 2.5 meters. In the work of Paula et al. (2010), evaluating ten popcorn genotypes, among them inbred lines of the Federal University of Viçosa, open pollination cultivars and hybrids, did not find materials higher than 1.90 meters. Of the ten, only one genotype had white grains; all the others had yellow-colored grains. Very tall plants are undesirable in the maize crop due to the possibility of lodging. However, it is a quantitative trait highly influenced by both the genotype and the environment. Studies of diversity in maize show the great amplitude that this characteristic can present. Oner and Gulumser (2014) found a height variation of 1.02 to 3.74 meters, in Turkey; Dar, Shakeel, and Verma (2018), 74,66 cm to 2.05 meters in Asia; Goodman and Paterniani (1969), 1.80 to 3.00 meters, in Brazil, and; Kizilgeci, Yildirim, Albayrak, and Bicer (2018), 1.65 to 3.15 meters, in Turkey.

Regarding the plant structure, the relationship between plant height, ear height and stem diameter is essential to avoid lodging. Thus, the EH/PH index is important, as it shows the relationship between the plant height and the height of the ear insertion. Values above 0.6 in this index are undesirable, as it means that the ear is exceedingly high in relation to the total height of the plant. In the work by Paula et al. (2010), with popcorn varieties and hybrids, the rates ranged from 0.53 to 0.60 . In the work of Scapim, Pacheco, Tonei, Braccini, and Pinto (2002), evaluating nine commercial varieties and their crosses, indexes between 0.41 and 0.57 and plant height between 1.31 and 1.70 were found. In the populations of this study, the index ranged from 0.35 to 0.68 . The lowest EH/PH indexes and plant height averages were found among yellow grain populations (Group III), which may suggest the occurrence of some level of previous breeding of these materials, due to the fact that one of the selection objectives takes into account the plant structure, and the preference for plants with low architecture, low insertion of the 1st ear, large number of grains and high amount of dry matter in the stem (Silva et al., 2021).

Regarding the stem diameter, popcorn in general has a smaller diameter than common corn. In the work of Dar et al. (2018), evaluating 10 varieties of common open-pollinated corn, the authors obtained an average stem diameter of $53.3 \mathrm{~mm}$ and a range of 35 to $63.3 \mathrm{~mm}$. Popcorn populations in this study ranged from 13.35 to $19.05 \mathrm{~mm}$, with an overall average of 15.56 $\mathrm{mm}$. The association of thin stem, high insertion of ear and tall plants favor lodging. However, populations such as $2152 \mathrm{~A}$, 2241 A, 778B and 123B, with average stem diameter of 16.8, 17.05, 17.34 and $19.05 \mathrm{~mm}$, respectively, and EH/PH of 0.57, 0.59, 0.52 and 0.50 , in that order, showed good characteristics of plant structure. In the work of Almeida et al. (2015), assessing the influence of organic fertilization on popcorn, the authors did not find stem diameters greater than $17.2 \mathrm{~mm}$.

The average length and number of branches of tassel was $42 \mathrm{~cm}$ and 18.9 branches, respectively. The length of the tassel was not related to the color of the grains, varying between populations of the same color. However, the number of branches of the tassel was higher in the varieties of black grain coloring (Group I), and of the nine varieties in this group, six (2604B, 123B, 2101B, 2526C, 123C and 236B) had more branches than the general average. As maize has apical dominance, large tassels are undesirable, as they drain photoassimilates, which could go to the ear and the grain. In addition, larger tassels produce more 
auxins, which have an inhibitory effect on ear development (Sangoi, Guidolin, Coimbra, \& Silva, 2006; Wartha et al., 2016). These factors may be associated with the lower weight of one thousand grains and the size of ears of this morphological group. However, larger tassels can contribute to more efficient pollination, as they release a larger amount of pollen.

Prolificity is a common characteristic in popcorn. However, in general, maize varieties are improved to produce one or two ears at most, in order to optimize the distribution of photoassimilates, producing larger ears and greater grain weight. In a study by Winkler, Ferreira, Iorkzeski, and Pereira (1998), in a trial with 15 varieties of popcorn, the authors found that the average number of ears ranged from 0.9 to 1.3, which means that some materials had plants without ears (average below 1) and others, plants with two ears per plant (average above 1). The inheritance related to the number of ears per plant is polygenic and strongly influenced by the environment. Under the conditions of this experiment, populations 2452A and varieties of Group I showed an average of 2.6 and 2.1 ears, respectively.

Prolific plants tend to produce smaller ears and grains. In this study, prolificacy was negatively correlated with weight of one thousand grains. Productivity and weight of one thousand grains are negatively correlated with the main character of importance in popcorn, the expansion capacity (Merlo, Fornasieri, \& Lam-Sánchez, 1988; Dofing, D`Croz-Mason, \& Compton, 1991; Daros et al., 2005). Studying a prolific variety of popcorn, Singh et al. (2016) observed that characteristics such as the thousand grains weight and size of ears were much smaller than other commercial materials. On the other hand, this variety showed an expansion percentage greater than $90 \%$. In this way, varieties that have greater prolificacy can contribute to obtaining materials with satisfactory productivity and good expansion capacity. Shandu (2012) studying inbred lines of popcorn, concluded that prolificacy is a promising characteristic for increasing yield and expansion in popcorn breeding programs.

As for the weight of one thousand grains, the populations showed notable variation. The general average of $139.13 \mathrm{~g}$ was similar to that found by Galvão, Sawazaki, and Miranda (2000), evaluating 40 simple hybrids and two commercial popcorn cultivars, with an average of $139 \mathrm{~g}$. If we consider the morphological groups found in this work, Group III had a weight of one thousand grains similar (140.1 g) to those mentioned above; however, Group I was below this value (110.4 g) and Group II was above (147.9). For this characteristic, populations 2079A and 2279X had the lowest and highest values, with 80.90 and $200.4 \mathrm{~g}$, respectively.

The local popcorn populations in this study showed circularity index values ranging from 0.64 to 0.8 , with population 2101B having the highest value and population 2138D having the lowest value. The circularity of the popcorn grains may be related to the expansion capacity. Pordesimo, Anantheswaran, Fleischmann, Lin, \& Hanna (1990), working with five varieties of popcorn, found a strong correlation between circularity and expansion capacity $(\mathrm{r}=0.87)$, concluding that small, short and wider grains, with higher values of circularity, presented higher values of expansion. In the work of Gonçalves, Mayer, Souza, \& Ogliari (2019), the authors found values from 0.24 to 0.32 for the circularity character of three popcorn cultivars. In that work, a positive correlation between circularity and expansion was also observed.

Studying populations of white grains from the FWSC, Gonçalvez et al. (2019) found plant height values ranging from 1.26 to $1.89 \mathrm{~m}$, ear height/plant height index between 0.39 and 0.66 and weight of one thousand grains between 119 and $216 \mathrm{~g}$. Furthermore, a positive correlation was found between circularity and expansion capacity. Being conducted in two environments, the study mentioned above shows the variability that the populations of the FWSC present for morphological characteristics. Another study with FWSC popcorn varieties (Seledes, Ogliari, Melhorança, Souza, \& Oliveira, 2019) used varieties with different grain colors and the results corroborates with the ones found in this work, in which the white colored varieties have longer cycle and have higher average plants. The black colored varieties showed lower values for weight of one thousand grain s and high prolificacy. This was also observed in the present study.

Regarding the cycle of materials, there was a wide range among populations, especially among populations of Group I. On the other hand, populations of Group III, formed by populations with grain characteristics closer to commercial materials 
(shorter plants, early cycle and round yellow grains), all needed to accumulate less than 770 ADD for tasseling. In the work of Barbano, Sawazaki, Brunini, and Boller (2003), evaluating three commercial popcorn cultivars, the authors found that all materials accumulated, on average, less than 800 ADD for tasseling. Seledes et al. (2019) observed that the FWSC populations with withe grains presented higher values of ADD for tasseling (up to 1007 ADD).

Olakojo, Olaoye, and Akintunde (2019), working with nineteen popcorn lines and one commercial cultivar, counting in days the subperiod between emergence and tasseling, found that the materials varied between 54 and 66 days, with average of 58.7. The populations in this study ranged from 52 to 77 days, with the lowest average (55.11 days) being found for the yellowcolored populations (Group III) and the highest average (73.65 days) for the white-colored populations (Group II).

Kizilgeci et al. (2018) found a variation equal to that found in this study, when evaluating 125 local varieties of maize, having a difference between the earliest variety (39.5 days) and the latest (64.5) variety of 25 days. Several studies show that the cycle in days varies depending on the genotype and environmental conditions (Idikut \& Kara, 2011; Kizlgeci et al., 2018). Thus, the most accurate way to assess the phenological cycle is through the method of thermal accumulation or degree-days.

Although the current Brazilian classification in relation to the cultivar cycle is suitable for improved materials, it does not allow for the adequate classification of materials with great diversity. Thus, as a classification of landraces in degree-days from emergency to tasseling, from the data obtained in this work, the following scale is suggested: < 800 ADD early; > 800 and $<900$ intermediate and > 900 late.

\subsection{Perspectives for race studies and breeding}

Although the classification of races in maize is carried out basically by ear and grain characteristics, the inclusion of plant characteristics may be important, since groups of plants with the same color and shape of grains, originated from the same geographical region, may have some similar plant morphological characteristics. For genetic breeding programs, this information could help in the identification of heterotic groups, generate new base populations, and broaden their genetic base. For ex situ conservation, this information is important to evaluate the diversity of the species in gene banks and the diversity between populations with similar grain characteristics, and thus helping with the elaboration of the best strategy for conservation and use of the germplasm. Usually, germplasm collections prioritize geographical axes and, in cases of microregions, such as the FWSC the usual form of collection may not represent the true variability present in that area. Thus, as shown by Vidal et al. (2018), the morphological diversity conserved on farm in addition with ethnobotanical information are fundamental for effective germplasm collection strategies.

When comparing the cluster of the present study with the popcorn races cluster by Silva et al. (2016), which evaluated 70 local popcorn varieties from FWSC (including the varieties of this study), it is possible to notice a similarity between the two studies, even though the current classification of races in maize is based just in ear and grain characteristics. For example, nineteen of the twenty populations of Group II of this study are grouped within the same race/group on the study of Silva et al. (2016). On the other hand, some differences with respect to the grouping also occurred due to the addition of plant characteristics in our research. Race III of the study by Silva et al. (2016), for example, was composed of populations from Groups I and III of the present study; populations 2423A and 2489E, which were previously grouped when using only characteristics of ear and grains, now appear as isolated populations when plant characteristics were added, showing the relevance of considering plant features for maize race studies.

Direct correlations of quantitative plant characteristics with qualitative attributes such as grain color are not possible, since Pearson's correlation between two characters is an exclusively quantitative analysis; however, indirect correlations may exist. In the present study, for example, it was observed that seven of the ten tallest plants belonging to Group II, which are plants 
with white-colored grains, are also the later plants to tasseling. The trend is reversed for varieties of Group III, yellow in grain color, with the plants being shorter and with less accumulated degree days.

In addition to the diversity observed between groups, the diversity within groups is also especially important for popcorn breeding.

In previous studies of Amaral Junior et al. (2011) and Silva et al. (2015) with country's recommended cultivars of popcorn, the authors showed the urgency to increase the genetic diversity of popcorn breeding programs of public and private institutions, since the genetic diversity of the recommended cultivars in Brazil is very narrow. This diversity within groups can be observed in the range of values obtained for some characteristics in our study, such as the variation in ADD for tasseling from 874 to 1090.5 for Group II, and plant height of Group I that ranged from 2.13 to $3.17 \mathrm{~m}$. Thus, cycle and some plant characteristics may have relation with grain and ear attributes, but the diversity observed for these features must be addressed, being relevant for conservation and breeding.

In a more recent study, Silva et al. (2020), evaluating the genetic diversity of 66 popcorn populations of the FWSC with single nucleotide polymorphism markers (SNPs), showed that the populations with similar grain color and shape were grouped by the genetic markers. In this way, Amaral Júnior et al. (2011)'s study also was enlightening in characterizing the diversity of white-colored popcorn in comparison to other types of corn by means of inter simple sequence repeats (ISSR) markers. The authors observed the formation of a group composed exclusively of popcorn with white-colored grains indicating the possibility of formation of heterotic groups from the color of the grains. So, both studies using genetic markers corroborate with the results obtained in this study using phenotypic characteristics, since the groups were formed based on the similar appearance of the grains in each case. Moreover, these works are good evidence to state that popcorn populations with similar color and shape of grain may be indicative of the formation of heterotic groups.

That way, in addition to the study of races, the information found in the present study is also important for the popcorn breeding programs, serving as subsidies for future studies, both for the evaluation of the genetic potential of intervarietal hybrids, and for the formation of composed populations, between groups and within group.

In the maize genetic breeding, for example, it is common to evaluate crosses of materials from different groups, such as in the formation of diallelic ones, in order to develop improved populations. Schemes of diallel crosses can be obtained both from pure lines and from varieties with a broad genetic base, making it possible to infer about the types of existing gene action, the action of the genes involved in important characters, as well as the heterotic potential and general and specific combination capacities of genotypes (Hallauer et al., 2010). In this respect, diallel analysis could help verify the heterosis components between groups from a facilitated process of group identification, and consequently, contribute to significantly increase the productivity of the crop.

The results of this study showed that popcorn populations with the same grain color and shape have some plant characteristics that were more prominent in that group. If a heterotic group is made up of a set of genotypes with a rich genetic inheritance, showing a trend of similarity for the most of the crop's morphological characteristics, then heterotic groups in popcorn could be indirectly defined by the grain color and shape.

Considering the variability between the populations of the same group, one possible way of popcorn improvement is the formation of populations composed from the crossing between local varieties of the same group. Such strategy allows the improvement of important characteristics at the same time that it guarantees the conservation of variability, forming and broadening the genetic base of new compounds. This is a significant aspect, considering that there are studies that show the narrow genetic diversity of Brazilian popcorn cultivars and the importance of the formation of compounds to improve the characteristics of interest, based on the selection within populations.

Finally, the formation of composed populations could also contribute to the improvement of conservation strategies in 
germplasm banks in order to keep population variability with similar profiles of grains, ears and plant morphological attributes, optimizing the space dedicated to conservation and subsequent use of this diversity by the breeding programs.

The results of the present study serve as a basis for further studies that aim of evaluating the heterotic potential between popcorn varieties with different colors and grain shapes, and thus contribute to the broadening the genetic base of popcorn breeding programs in Brazil. They can also contribute to new studies of races in popcorn, aiming to better understand how the diversity of this type of corn is distributed from plant, grain, and ear characteristics.

\section{Conclusion}

There is significant diversity in terms of plant characteristics and phenological cycle for local FWSC popcorn populations, even within populations in the same grain morphological group. The morphological groups with similar grain colors were grouped, even when the characteristics expressed in the plant are included in the analysis. Trends in some plant characteristics were observed within groups of same grain color, indicating a possible relation of grain color with heterotic groups in popcorn.

\section{Acknowledgments}

To farmers and local FWSC organizations. To the financial support agencies: Co-ordination for the Improvement of Higher Education Personnel - CAPES, Federal University of Santa Catarina - UFSC.

\section{References}

Abdi. H., \& Williams, L. J. (2010). Principal Component Analysis. Wiley Interdisciplinary Reviews 2:1-47.

Almeida, D. J., Silva, I. F., Souza, R. F., Silveira, F. P. M., Santos, L. S., \& Malta, A. O. (2015). Influência da adubação orgânica e densidade de plantio na produção do milho pipoca. Pesquisa Agropecuária Pernambucana 20:17-21. 10.12661/pap.2015.003

Amaral Júnior, A. T., de Oliveira, E. C., Gonçalves, L. S. A., Scapim, C. A., Candido, L. S., Silva, T. R. C., Vittorazzi, C., \& Cunha, K. S. (2011). Assessment of genetic diversity among maize accessions using inter simple sequence repeats (ISSR) markers. Afr. J. Biotechnol. 10:15462-15469. 10.5897/AJB10.2624

Anderson, E., \& Cutler, H. C. (1942). Races of Zea mays: I. Their recognition and classification. Ann Mo Bot Gard 29:69-88

Barbano, M. T., Sawazaki, E., Brunini, O., \& Boller, P. (2003). Base temperature and accumulated growing degree days for popcorn maize cultivars (Zea mays L.) for the sub-period sowing- flowering phase. Rev. Bras. Agromet. 11:79-84

Borras, F., Seetharaman, K., Ni Yao., Robutti, J. L., Percibaldi, N, M., \& Eyheraide, G. H. (2006). Relationship between popcorn composition and expansion volume and discrimination of corn types by using zein properties. Cereal Chem 83:86-92. http://dx.doi.org/10.1094/CC-83-0086

Brazil (1997) Descritores mínimos do Milho (Zea mays L.) Ministério da Agricultura Pecuária e Abastecimento. 1-10.

Costa, F. M., Silva, N. C de A., \& Ogliari, J. B. (2016). Maize diversity in southern Brazil: indication of a microcenter of Zea mays L. Genet Resour Crop Evol 64:681-700. 10.1007/s10722-016-0391-2

Dar, T. H., Shakeel, R., \& Verma, S. (2018). Comparative Germplasm Characterization of Maize (Zea mays L.) in Rajouri Region of Pir Panjal Himalaya J \& K (India), based on Morphological and ISSR Markers. J. Crop Sci. Biotech. 21: 43-55. 10.1007/s12892-017-0128-0

Daros, M., Amaral Júnior, A.T., Pereira, M. G., Santos, F. S., Scapim, C. A., Freitas Júnior, S. P., Daher, R, F., \& Ávila, M. R. (2005). Correlações entre caracteres agronômicos em dois ciclos de seleção recorrente em milho-pipoca. Ciência Rural 34:1389-1394. 10.1590/s0103-84782004000500010

Dofing, S. M., D‘Croz-Mason, N., \& Compton, M. A. T. (1991). Inheritance of expansion volume and yield in two popcorn x dent corn crosses. Crop Science, 31:715-718. https://doi.org/10.2135/cropsci1991.0011183X003100030035x

Galvão, J. C. C., Sawazaki, E., \& Miranda, G. V. (2000). Comportamento de Híbridos de Milho-Pipoca em Coimbra, Minas Gerais. Revista Ceres, 47:201-2018

Gama, E. E. G., Magnavaca, R., Silva, J. B., Sans, L. M. A., Viana, P. A., Parentoni, S. N., Pacheco, C. A. P., Correa, L. A., \& Fernandes, F. T. (1990). Milho pipoca. Informe Agropecuário. 14:8-12. 
Gonçalves, G. M. B., Mayer, L. B., Souza, R., \& Ogliari, J. B. (2019). Yield and popping expansion components in local popcorn varieties from Southern Brazil. Acta Agronômica. 68:213-221. doi 10.15446/acag.v68n3.69127

Goodman, M. M. \& Paterniani, E. (1969). The races of maize: III. Choices of appropriate characters for racial classification. Econom. Bot., 23:265-273. https://doi.org/10.1007/BF02860459

Gorjanc, G., Jenko, J., Hearne, S. J., \& Hickey, J. M. (2016). Initiating maize pre-breeding programs using genomic selection to harnedd polygenic variation from landrace populations. BMC Genomics. 30: 1-15. 10.1186/s12864-015-2345-Z

Gower, J. C. (1971). A general coefficient of similarity and some of its properties. Biometrics. 27: 857-874.

Hallauer, A. R., Carena, M. J., \& Miranda Filho, J. B. (2010). Quantitative Genetics in Maize Breeding. Originally published by Iowa State University Press, 1988 3rd ed. XVI, p.664.

Hammer, Ø., Harper, D. A.T., \& Ryan, P. D. (2001). PAST: Paleontological Statistics Software Package for education and data analysis. Palaeontol Electron 4(1):1-9

Idikut, L., \& Kara, S. N. (2011). The effects of previous plants and nitrogen rates on second crop corn. In Turkish. J. Field Crops 16:239-244.

IPGRI - International Plant Genetic Resources Institute (2000) Descriptors for maize/descriptores para maiz/descripteurs pour le maïs. International Board for Plant Genetic Resources, Rome

Kist, B.B. (2018). Annual maize book 2018. Editora Gazeta, Santa Cruz do Sul, 88p.

Kizilgeci, F., Yildirim, M., Albayrak, O., \& Bicer, B. T. (2018). Evaluation of Turkish maize landraces through observing their yield and agro-morphological traits for genetic improvement of new maize cultivars. Acta fytotechn zootechn. 21:31-43. 10.15414/afz.2018.21.02.31-43

Lee, M. (1995). DNA markers and plant breeding programs. Advances in Agronomy, 55: 265-344. https://doi.org/10.1016/S0065-2113(08)60542-8

Merlo, E., Fornasieri, F. D., \& Lam-Sánchez, A. (1988). Avaliação de sete cultivares de milho pipoca (Zea mays, L.) em três densidades de semeadura. Científica, $16: 245-251$

Miranda, G. V., Coimbra, R. R., Godoy, C. L., Souza, L. V., Guimarães, L. J. M., \& Melo, A. V. (2003). Potencial de melhoramento e divergência genética de cultivares de milho-pipoca. Pesq. agropec. bras, 38:681-688. https://doi.org/10.1590/S01100-204X2003000600003

Munhoz, R. E. F., Priori, A. J., Amaral Júnior, A. T., Scapim, C. A., \& Simon, G. A. (2009). Genetic distances among popcorn populations based on molecular marker and the correlations with the heterosis estimates on the hybrids made by diallel analysis. Genetics and Molecular Research 8: 321-328. 10.1590/S198470332010000400002

Nass, L. L., \& Paterniani, E. (2000). Pre-Breeding: A link between genetic resources and maize breeding. Scientia Agricola 57: 581-587. https://doi.org/10.1590/S0103-90162000000300035

Neto, R. F. (2013). Técnicas experimentais e suas relações com a Lei de Proteção de Cultivares. Piracicaba. Univerisdade de São Paulo. 12p.

Nobre, R. G., Liberalino Filho, J., Praça, E. F., Dias, S. N., \& Neto, M. F. (2000). Avaliação da qualidade de diferentes marcas comerciais de milho-pipoca. Rev Bras Eng Agrícola e Ambient 4:133-135. 10.1590/s1415-43662000000100025

Olakojo, O., Olaoye, G., \& Akintunde, A. (2019). Performance of popcorn introductions for agronomic characters, grain yield and popping qualities in the forest and derived savannah agro-ecologies of Nigeria. Acta Agri. Slov. 114: 53-60. 10.14720/aas.2019.114.1.6

Oner, F., \& Gulumser, A. (2014). Determination of Some Agronomical Characteristics of Local Flint Corn (Zea mays L. indurata) Genotypes in The Black Sea Region of Turkey. Türk Tarım ve Doğa Bilimleri, 7:1800-1804

Paraginski, R. T., Souza, N. L., Alves, G. H., Ziegler, V., Oliveira, M., \& Elias, M. C. (2016). Sensory and nutritional envaluation of popcorn kernels with yellow, white and red pericarps expanded in different ways. Jour. Cer. Sci. 69: 383-391. http://dx.doi.org/10.1016/j.jcs.2016.05.013

Paterniani, E., Nass, E., \& Santos, M. X. (2000). O valor dos recursos genéticos de milho para o Brasil - uma abordagem histórica da utilização do germoplasma. In: Udry, C. V., Duarte, W. (ed) Uma história brasileira do milho - o valor dos recursos genéticos. Paralelo 15, Brasília, pp 11- 42.

Paula, T. O. M., Gonçalves, L. S. A., Amaral Júnior, A. T., Oliveira, E. C., Silva, V. Q. R., Scapim, C. A., \& Lopes, A. D. (2010). Magnitude of the genetic base of commercial popcorn and in recommendation in Brazil. Crop Breed Appl Biotechnol 10:289-297. 10.1590/s 1984-70332010000400002

Pordesimo, L. O., Anantheswaran, R. C., Fleischmann, A. M., Lin, M. A., \& Hanna. (1990). Physical Properties as Indicators of Popping Characteristics of Microwave Popcorn. J Food Sci 55:1352-1355. 10.1111/j.1365-2621.1990.tb03934.x

Ritchie, S. W., Hanway, J. J., \& Benson, G. O. (2003). Como a Planta De Milho se Desenvolve. Potafos: Informações Agronômicas n¹03 (80) 1-20

Sangoi, L., Guidolin, A. F., Coimbra, J. L. M., \& Silva, P. R. F. (2006). Response of maize hybrids grown at different eras to plant population and tassel removal. Cienc. Rural 36: 1367-1373. http://dx.doi.org/10.1590/S0103-84782006000500004 
Sawazaki, E. (2010). Milho pipoca. In: Congresso Nacional de Milho e Sorgo. http://www.abms.org.br/eventos_anteriores/cnms2010/palestras/010.pdf. Acessed 17 april 2019.

SBCS - Sociedade Brasileira de Ciência do Solo (2004) Manual de adubação e de calagem para os estados do Rio Grande do Sul e de Santa Catarina (ROLAS). Sociedade Brasileira de Ciência do Solo -Núcleo Regional Sul, Porto Alegre, Brazil

Scapim, C. A., Pacheco, C. A. P., Tonei, A., Braccini, A. L., \& Pinto, R. J. B. (2002). Análise Dialélica e Heterose de populações de milho pipoca. Bragantia 61:219-230. https://doi.org/10.1590/S0006-87052002000300003

Seledes, R. M., Ogliari, J. B., Melhorança, E. A. L., Souza, R., \& Oliveira, W. B. S. (2019). Caracterização fenotípica de milho-pipoca conservado in situ-on farm no Extremo Oeste de Santa Catarina. Agropecuária Catarinense. 32:56-61.

Shandu, S. (2012). Genetic Diversity, Correlations and Path Coefficient Analysis in Popcorn (Zea mays L. everta). Dissertation, University of KwaZulu-Natal, South Africa. $150 \mathrm{p}$.

Silva, D. F., Garcia, P. H. M., Santos, G. C. L., Farias, I. M. S. C., Pádua, G. V. G., Pereira, P. H. B., Silva, F. E., Batista, R. F., Neto, S. G., \& Cabral, A. M. D. (2021). Características morfológicas, melhoramento genético e densidade de plantio das culturas do sorgo e do milho: uma revisão. Research, Society and Development. 10:1-9. https://doi.org/10.33448/rsd-v10i3.13172

Silva, N. C. A., Vidal, R., \& Ogliari, J. B. (2016). New popcorn races in a diversity microcenter of Zea mays L. in the Far West of Santa Catarina, Southern Brazil. Genetic Resources and Crop Evolution 64:1191-1204. 10.1007/s10722-016-0429-5

Silva, N. C. A., Vidal, R., Ogliari, J. B., Costich, D. E., \& Chen, J. (2020). Relationships among American popcorn and their links with landraces conserved in a microcenter of diversity. Genetic Resources Crop Evolution 67: 1733 - 1753. https://doi.org/10.1007/s10722-020-00935-2

Silva, T. A., Cantagalli, L. B., Saavedra, J., Lopes, A. D., Mangolin, C. A., Machado, M. F. P. S., \& Scapim, C. A. (2015). Population structure and genetic diversity of Brazilian popcorn germplasm inferred by microsatellite markers. Eletronic Journal of Biotechnology. 18: $181-187$. http://dx.doi.org/10.1016/j.ejbt.2015.03.005

Singh, A., Singh, S. B., Dutta, S. K., Boopathi, T., Singson, L., Saha, S., Devi, M. T., \& Singh, N. H. (2016). Multi cob-bearing popcorn (Puakzo) maize: A unique landrace of Mizoram, North East, India. Curr. Sci. 110:1392-1393

Souza, A. M., Ethur, A. B. M., Lopes, L. F. D., \& Zanini, R. R. (2002). Introdução a projetos de experimentos: caderno didático. 119p.

Srdić J, Milašinović ŠM, Radosavljević M, Radosavljevic, M., Kravić, N., \& Babić, V. (2017). Evaluation of agronomic and sensory characteristics of the popcorn kernel. J Process Energy Agric 21:185-187. 10.5937/JPEA1704185S

Vendruscolo, E. C. G., Scapim, C. A., Pacheco, C. A. P., Oliveira, V. R., Braccini, A. L., \& Vidigal, M. C. G. (2000). Adaptabilidade e estabilidade de cultivares de milho-pipoca na região centro-sul do Brasil. Pesq. Agropec. Bras. 36:123-130. https://doi.org/10.1590/S0100-204X2001000100015

Vidal, A. R. (2016). Diversidade das populações locais de milho de Anchieta e Guaraciaba, Oeste de Santa Catarina: múltiplas abordagens para sua compreensão. Thesis, Federal University of Santa Catarina, 188p.

Vidal, A. R., Silva, N. C. A., \& Ogliari, J. B. (2018) Old tools as new support for on farm conservation of different types of maize. Scientia Agricola. 77: 1-9. http://dx.doi.org/10.1590/1678-992X-2018-0091

Vilaró, M., Vidal, R., \& Abadie, T. (2020). Diversity of Maize Landraces in Germplasm Collections from South America. Agrociencia. 77: 1-11. http://dx.doi.org/10.31285/agro.24.108

Vittorazi, C., Amaral Júnior, A. T., Guimarães, A. G., Silva, F. H. L., Pena, G. F., Daher, R. F., Gerhardt, I. F. S., Oliveira, G. H. F., Santos, P. H. A. D., Souza, Y. P., Kamphorst, S. H., \& Lima, V. J. (2018). Evaluation of genetic variability to form heterotic groups in popcorn. Gen. Mol. Res, 17 (3): 1-17. https://doi.org/10.4238/gmr18083

Wartha, C. A., Cargnelutti Filho, A., Lúcio, A. D., Follmann, D. N., Kleinpaul, J. A., \& Simões, F. M. (2016). Sample sizes to estimate mean values for tassel traits in maize genotypes. Genet Mol Res 15:. 10.4238/gmr15049151

Winkler, E. I. G., Ferreira, F. I., Iorkzeski, E., \& Pereira, L. R. (1998). Avaliação de Cultivares de Milho Pipoca em Passo Fundo e Pelotas 1997/98. Agrop. Clima Temp, 2:281-288

Zinsly, J. R., \& Machado, J. A. (1978). Milho-pipoca. In: Melhoramento e produção de milho no Brasil. Fundação Cargill. pp 339-3

Zsubori, Z., Gyenes-Hegyi, Z., Illés, O., Pók, I., Rácz, F., \& Szöke, C. (2002). Inheritance of Plant and Ear Height in Maize (Zea Mays L.). Acta Agraria Debreceniensis, 8:34-38. 10.34101/actaagrar/8/3548 